Jurnal The Messenger, Vol. 10, No. 1, January 2018, pp. 44-53

P-ISSN: 2086-1559, E-ISSN: 2527-2810

DOI: $10.26623 /$ themessenger.v10i1.671

\title{
Hashtag (\#) as Message Identity in Virtual Community
}

\section{Tanda Pagar (\#) sebagai Identitas Pesan pada Komunitas Virtual}

\author{
Urip Mulyadi ${ }^{1}$, Lisa Fitriana ${ }^{2}$ \\ ${ }^{1}$ Study Program of Communication Science, Universitas Islam Sultan Agung Semarang, \\ Jl. Kaligawe Raya Km. 4, Terboyo Kulon, Genuk, Semarang 50112, Indonesia \\ ${ }^{2}$ Magister of Communication Science, FISIP, Undip, Jl. Erlangga Barat VII No. 33, \\ Semarang 50241, Indonesia \\ *Corresponding author, e-mail: oeripmulia@unissula.ac.id
}

\begin{abstract}
Computer Mediated Communication or CMC is able to present a virtual community, where the people inside have the same interest to share information related to events, activities, competitions, entertainment, history, event and others in Semarang City for publication. This research attempted to describe that hashtags can be utilized as the identity of a message in a communications network on Facebook Group MIK Semar. The results of this study are hashtags have changed how we build a virtual community, as the use of hashtags in facebook group MIK SEMAR as message identity to build better relationship and support communication among its members.
\end{abstract}

Keywords: Virtual Community, Social Media, Hashtags.

\begin{abstract}
Abstrak
Computer Mediated Communication atau CMC mampu menghadirkan komunitas virtual, dimana orang-orang yang ada di dalamnya memiliki kepentingan yang sama untuk saling berbagi informasi terkait dengan peristiwa, kegiatan, lomba, hiburan, sejarah, event dan lainlain di Kota Semarang untuk dipublikasikan. Penelitian ini bertujuan untuk menggambarkan bahwa hashtag atau tanda pagar (\#) mampu dimanfaatkan sebagai identitas pesan dalam jaringan komunikasi pada Grup Facebook MIK Semar. Hasil Penelitian ini adalah hashtags telah mengubah bagaimana kita membangun sebuah komunitas virtual, sebagaimana penggunaan hashtags dalam komunitas virtual Grup Facebook MIK SEMAR sebagai identitas pesan untuk membangun hubungan yang baik dan mendukung komunikasi antara anggotanya.
\end{abstract}

Kata Kunci: Komunitas Virtual, Media Sosial, Hashtags.

Copyright (C) 2018 Universitas Semarang. All rights reserved.

\section{Introduction}

The development of technology has been able to attract various levels of society to create new community in cyberspace. The presence of social media is used as a source of information society has changed the pattern of social or individual interaction. Media social also provides space for freedom for all media users who are assessed as part of their lifes. According to Kaplan and Haenlin (2010: 59) social media is an easy channel to participate, share and create blog content, social networking, wikis, forums in the virtual world. Social media as "a collection of internet-based applications which are built on the ideology and technology of web 2.0", and which enables the arising of "user-generated content". Flew (in Watie, 2012: 15) explains, the new media is a medium that offers digitization, convergence, interactiviy, and network development related to producing and message delivering.

Article History: Received November 18, 2017; Revised January 18, 2018; Accepted January 27, 2018; Published January 31, 2018 
Like a discussion forum, a web forum can also accommodate ideas, opinions and all the information from its members as well as exchange the thoughts with each other. An online forum usually has a certain subject, but does not rule out expanding to various subjects. In obstacles, online forums are a bulletin board available in the form of online. But currently, an online forum may just happen, not as minimal as the information symbolizes between the same user and forum owner (Hermawan, 2009: 12) .One of the social media that is often used to form an online community is Facebook. Facebook usage can make it easier for someone to find new or old friends, information on the latest topics, to gather in an online community in an effort to build an opinion.

According to research reports "We Are Social and Hootsuite" (2017), which was launched in April, It showed the existence active media social user more about 1968 billion. The first rank is occupied by the United States with 219 million users or $11 \%$, second is India with 213 million users or $11 \%$, followed by Brazil with 123 million users or $6 \%$ and Indonesia with 7 with 123 million users or $6 \%$. In addition, according to a survey which was conducted by the Association of Internet Service Providers Indonesia (APJII) in October 2016 (APJII, 2016) showed Indonesian internet users is 132.7 million of the total population of Indonesia 256.2 million people. If we notice the users of both surveys show more than $90 \%$ of Facebook users in Indonesia where $65 \%$ of internet users are located in Java Island.

Today, internet is the only one and the most important construction which is built in contemporary communications, it is produced globally "public spaces" where in the theory, every individual can access or involve directly in global forums where they are allowed to express their arguments without mediation, selection or sensors. However the thing should be questioned is, how massive the chats are happening in online forums like youtube, myspace, facebook and blogs, chatrooms will meet the criteria of public space conditions as a forum for criticizing and rational debate. The important thing is that we understand the arena of ideology Jurgen Habermas in the concept of "public space". Habermas defines public space as "the realm where our social life in a matter seen as public opinion can be formed" (Habermas in Ubayasiri, 2006: 4).

Currently, in Indonesia a lot of emerging virtual communities that are formed based on the region in both the district level, City and Province. Such as Ungaran Group, Kabar Salatiga, Liputan Terkini Kendal, Media Informasi Kota Demak, Media Informasi Bojonegoro and others. Each virtual community has a varying number of members, the average number of tens of thousands or even hundreds of thousands.

One of the existing online forums is Facebook Group Media Information Semarang City Grup Facebook Media Informasi Kota Semarang (MIK SEMAR). MIK SEMAR is a big house in cyberspace for the citizens of Semarang to share information among the people about events, competitions, entertainment, history and others in Semarang for publically published.

Facebook Group Media Information Semarang City (Grup Facebook Media Informasi Kota Semarang (MIK SEMAR)) is a group known as a container of aspirations, criticism, and all issues related to the city of Semarang delivered cyberspace (netizens), as quoted from the Facebook group page, MIK SEMAR, until November 2017 is a member or members of the MIK Semar Group has reached 322,360 facebook users, this group is also the most considerable member among other facebook group in Semarang with the number of active uploads reach 4530 uploads. Other Facebook groups include Semarang City Information (Informasi Seputar Kota Semarang (ISKS)) with 15,738 members, Semarang Public Information Media (Media Informasi Publik

Jurnal The Messenger, Vol. 10, No. 1, January 2018, pp. 44-53 
Semarang (MIP Semar)) with 7,935 members (members), and Semarang 20,154 members (members).

This Facebook group allows everyone to be able to share information with other audiences among all members. Member in the group has the authority to choose and create their own opinions they want. MIK Semar Group, the public is given the freedom to express their opinions, but must be responsible for their uploads. It means that uploads do not contain SARA or racism, pornography and are not contrary to law in Indonesia, in this case is the ITE Law.

MIK Semar is known by the existence of Main Manipulator "Dalang Utama". He or she is the administrator who has the authority to control and to be the leader in virtual world group. Under Main Manipulator "Dalang Utama" there is a "Punggawa". It is an administrator filtering various uploads that are considered contrary to the rules of the Group. In this group is also known as "Friday Freeday" and "Weekend no filter" where all members may post anything without getting ACC (Accepted) from the group admin who has the right to filter the uploads. People who join in this group has the freedom to upload anything as long as it is not against the rules of the group, yet if this freedom is not utilized as good as possible by the group members, as a result there are some uploads that are not worth to read. It leads to the MIK Semar group being uncontrolled and can not be enjoyed.

Therefore, the last "Friday Freeday" and "Weekend no filter" given on 20-22 October, 2017, brings up to a new regulation for its members who want to upload information (Postingan). The new regulation is that every upload must use hashtags (\#). This hashtag will be a mandatory requirement that must be included in each upload to be in ACC (Accepted) or approved by the group administrator.

Basically the use of hashtags (\#) was first introduced by social media "twitter" to classify messages (tweets) with specific topics, which also allows other users to search and share the same topic. Hashtag usually consists of a series of characters (possibly including numeric numbers) preceded by the pound symbol (\#) which is also called a hash). This combination has function as a label for the message itself and "linked to a search for those characters".

Time goes by, the use of hashtags has also penetrated into other social media, including Instagram, Google+ and Facebook since 2013. Moreover, hashtags are no longer limited to the online world but also emerged in the linguistic landscape and in various offline contexts such as political slogans and speech, social movements, advertising world, and television programs.

MIK Semar Group has become the second home for Semarang residents to gather and share information, so it needs to be maintained its existence. One of them is the use of hashtags on each upload. Because basically, Facebook is a very easy to use application with free registration which is available in various languages and includes various features to communicate.

The problem in this research is how hashtag (\#) can be utilized as message identity in communication network on Facebook Group MIK Semar. The context of this study focuses on Facebook social media where there is a virtual community or public group that uses hashtags to support communication among its members. Hashtag can also be a movement or knowledge developemnt to spread ideas, news, or opinions on a particular topic. This is interesting to investigate because the use of the internet is increased in Indonesia, of course this will make the new Facebook Group will continue to be created with various purposes and usability. 
In this research is about the using of social networking site Facebook. Therefore, this research is a form of Computer Mediated Communication, where communication transactions that occured through the use of two or more computer networked. The term describes communication that occurs mediated by the computer format, for example: instant messaging, chat rooms, e-mail. The format is applied to other forms of textbased interaction such as text messages.

Meanwhile, the notion of "community" has long held an important position in social theory, particularly as a tool for assessing the impact of social change and as the neutralizing idea of the masses. In earlier thinking, the community refers to a group of people sharing space (or limited space), a particular identity and norms, values, cultural practices, and usually small enough to get to know each other and to interact. Communities of this type usually exhibit some of the distinctive traits based on their status and members, and thereby indicate the hierarchy and form of informal organization. A series of new hopes about the growing community surrounding computer-mediated communication (CMC).

$\mathrm{CMC}$ and the Development of Virtual Communities

Computer Mediated Communication (CMC) is defined as a process of communication made through computers, involving humans occurring in certain contexts, which involves the process of media forming for various purposes. This is in accordance with the definition of computer-mediated communication namely: "Computer Mediated Communication is a process of human communication via computer, involving people, situated in particular context, engaged in process to shaped media for variety of purpose" (Thurlow et al, 2007: 15).

In essence, $\mathrm{CMC}$ is a process of communication or exchange of information that is done through a computer medium. The presence of the virtual world, opens the opportunity of each party involved to his existance wider. All the more for those who are active in social media. Through status, comments, notes, and various facilities in social media that many people show their existence by continuing to update every existing developments (Watie, 2011: 73).

Computer Mediated Communication or CMC is able to bring the community. The term virtual community is used to describe the level of commitment and openness experienced by users. Rheingold emphasizes CMC users to establish continuous relationships. CMC is a social aggregation when many people bring long enough public discussion, with a human feeling to form a personal relationship in cyberspace (Hine, 2000: 16-17).

A virtual community as a deliberately founded community of people with the same interests that often revolves around a particular text or phrase taken from nonCMC places (Lindolf \& Schatzer in McQuail, 2011: 163-164). Although communication which is mediated by the computer offers new opportunities to cross social and cultural boundaries, it also indirectly reinforces the same boundaries. They want to be part of the community in cyberspace, they must adapt themselves to the norms and rules to be recognized and accepted (Postman in McQuail, 2011: 165).

\section{Methodology}

The method used in this study is a qualitative approach. It is a research that the results are not realized in the calculation of numbers but described in writing. Qualitative research is subjective, depending on the experience of the researcher and the 
investigator, in exploring events during the course of the study, or cutting it off if it does not fit the problem under study (Greenhalgh \& Taylor, 1997: 2).

Researchers will more direct to the analysis of qualitative data because it involves the activities and dynamics that occur in a virtual cultural environment. This study focuses on searching documents and online data related to the use of hashtag (\#) on Facebook Group MIK Semar. Social media in this context relates to the entire network to communicate using the internet, chosen purposively and not limited to the location of its use, because the preferred is about hashtag uploading in the Facebook Group MIK Semar, which is to look at various libraries, printing or online documents that the number is very massive and deliberately chosen that there is a connection on the research topic.

This technique includes selection based on certain criteria made by researchers and research puprposes. Usually purposive sampling techniques are chosen for research that prioritizes depth of data rather than to generalize representational purposes (Kriyantono, 2007: 154-155). Data analysis technique in this research uses three activity flows that is data reduction, data presentation, and conclusion (Miles \& Huberman, 2009: 19). The essence of qualitative data analysis lies in the process of linking statements to describe phenomena, to classify, and to see the concepts connected thoroughly as a result of scientific research (Dey, 1993: 31).

The data are processed in a number of categories that lead to generalization efforts to be presented in an interpretative and descriptive manner. The collected data is thematically compiled based on the information obtained. Data compilation is done by sorting relevant to the research problem.

\section{Result and Discussion}

MIK Semar Facebook Group that provides the rules to be obeyed all its members, here are the rules for all members of Facebook Group MIK Semar (https://web.facebook.com/groups/MIKSEMAR):

1. The contents of the post shall not contain racism SARA, pornography, contrary to law in Indonesia.

2. The information is provided in complete, clear, accurate (Who, By Whom, When, Where, With What, How).

3. Legal acts relating to other parties/persons, are required to attach a Letter of Police Report.

4. It does not contain personal outpouring or self-image photos.

5. Promotion Sale or Purchase of goods/services is allowed every Saturday from 00:00 to Sunday 23:59 pm (with NOT the goods/services that are prohibited or limited circulation).

6. Post accident victim MUST BE BLURRED to honor victims and family.

7. If news content is the result of sharing from elsewhere, it is required to include the source of the news.

8. Provide a useful post for all members of MIK SEMAR group.

9. Each member is expected to fully support government policy for shared comfort, security and safety (such as NOT TO share Location of Order Operations).

10. Expected before giving information, check first whether it has existed or not (NO doubel post).

11. Participate in keeping the group for the sake of convenience together, the contents of the infringing posts can be reported (report) to the admin for deletion. 
12. Any Content of the mail shall be the sole responsibility of the sender.

Hashtags or Signs (\#) as Message Identity

Social media has bring out to a new form of communication and interaction with the public. One of the most innovative tools is the hashtag. Since a Twitter employee named Chris Messina sent the first tweet containing a hashtag in 2007, hashtags have become popular and spread to other social media platforms. Hashtag shows topics or themes, and it is an important innovation in communication in social media. The use of hashtags is very powerful because it is so participatory. Hashtag is not decided by a predefined set of users. The hashtag system is a tagging, organizing, and classification system. Hashtags to classify messages, to improve searching, and to enable organizations to link messages to emerging topics and communities incorporated in the hashtag. In short, the hashtag can lead the formation of an "ad hoc public" or public network that develops around the hashtag (Bruns \& Burgess, 2011).

This network/community can be brief and arise in response to emergencies or crises. Hashtag can also be a movement or knowledge developed to spread ideas, news, or opinions on a particular topic.

Hashtag has given a different color in social media, where social media has been equipped with User Generated Content (UGC) which create citizen involvement in social media. First, hashtags have changed how we speak (verbally or non-verbally), eg: the use of \#YesWeCan, \#Smile, \#GoodMorning hashtags that usually words or expressions are used in everyday life. Secondly, hashtags have changed how to sell a product or campaign, let's say the hashtags \#Paytreninaja, \#Business Opportunities, \#Supported, \#MakeAmericaGreatAgain, \# Salam2jari.

Third, hashtags have become an equipment to find the source of existing content in social media, for example we want to find information about job vacancy, we just need to type \#lowongankerja in the "search" available in social media then all information related to the vacancy will appear.

Fourth, hashtags have become new way in doing social movements, for example the use of hashtags \#SaveKPK, \#ShameOnYouSBY, \#Gerakan tAntiNarkoba and others who could become viral in social media. Fifth, hashtags have changed how we build a virtual community, because with the inclusion of hashtags followed by messages or quality content it will be easy to develop relationships within virtual communities, let's say the use of hashtags in the MIK SEMAR Group's facebook virtual community as message identity to build relationships better.

Since 2013, hashtags feature (\#) has been used on Facebook. In the MIK Semar Facebook group, hashtags (\#) are no longer used to group or associate similar topics but are used as the message identity of each file uploaded into the group, the use of hashtags is required by the group manager as submitted by Mastermind MIK Semar in its post is on October 23 , 2017 (https://web.facebook.com/groups/MIKSEMAR/permalink/1571344309649193/).

First, \#MIKSEMARTANYA to identify uploaded messages meant to ask about something into the Group. 


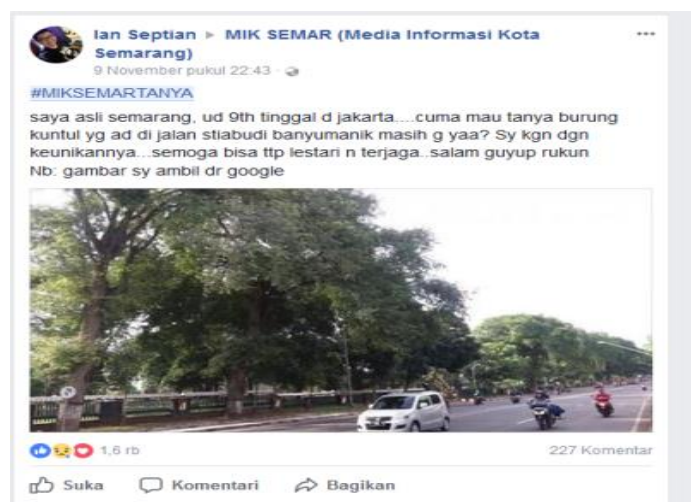

Figure 1. Sample of the Use of hashtags \#MIKSEMARTANYA

Second, \#MIKSEMARINFO to identify uploaded messages is meant to provide information to the group about events and its kind.

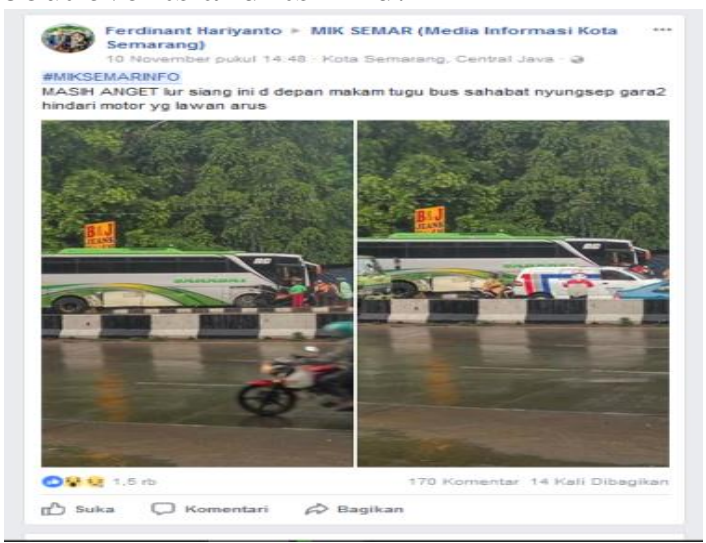

Figure 2. Sample of the Use of hashtags \#MIKSEMARINFO

Third, \#MIKSEMARLOKER to identify uploaded messages as information about job vacancy

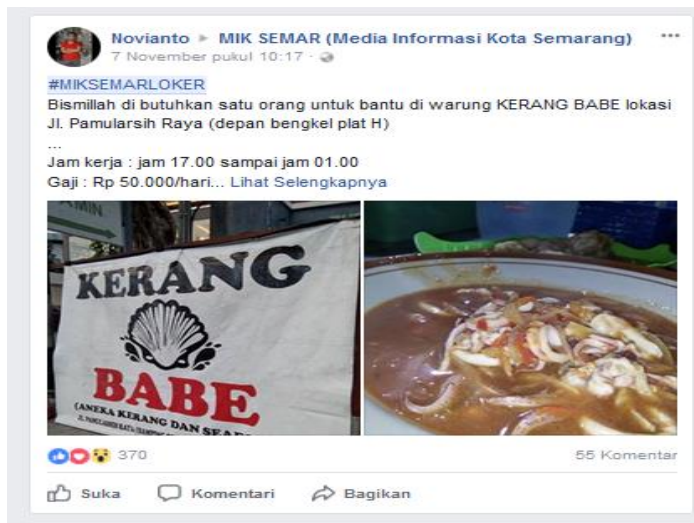

Figure 3. Sample of the Use of hashtags \#MIKSEMARLOKER

Fourth, \#MIKSEMARPROMOSI to identify uploaded messages as information about promoted product. Promoted products can be personal or impersonal. With \#MIKSEMARPROMOSI members or citizens of Facebook Group MIK SEMAR can make marketing efforts for free. 

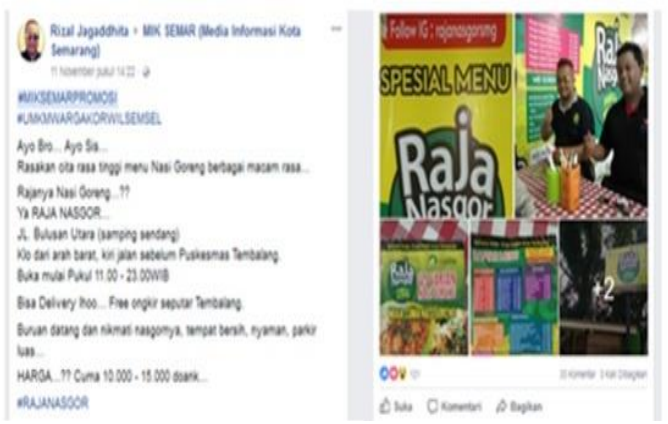

Figure 4. Samples the Use of hashtags \#MIKSEMARPROMOSI

Fifth, \#MIKSEMARSAPA to identify the uploaded message, It is intended as information containing all activities of members or citizens of Facebook Group MIK SEMAR in its role to build Semarang City, the post contents can be a picture or video with a complete list of what and how the activities of the citizens. In addition, \#MIKSEMARSAPA can also be utilized to greet childhood friends or schoolmate who don't meet up in very long time, the expectation through the Facebook Group MIK SEMAR that they can meet each other.

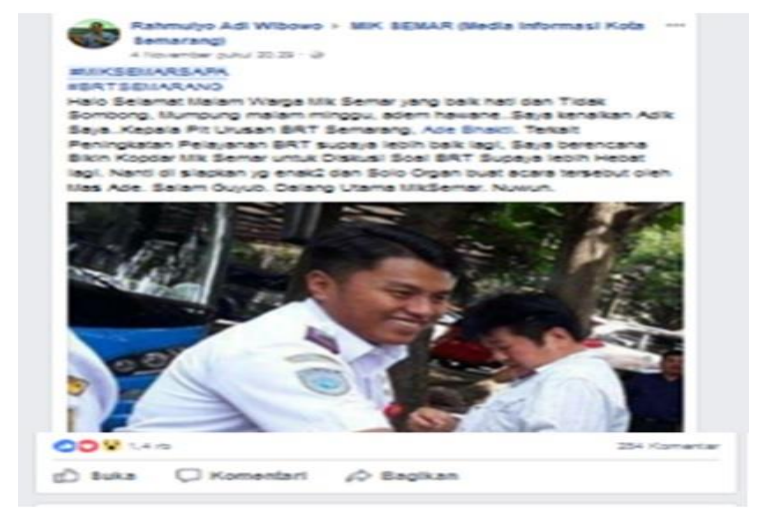

Figure 5. Sample the Use of hashtags \#MIKSEMARSAPA

Sixth, \#MIKSEMARTAWA for uploaded messages is intended as a funny story or picture that aims to entertain members or residents of the MIK SEMAR Facebook Group. \#MIKSEMARTAWA may contain cute writings, may be war images of nonnegative, or funny videos. The joke of Mik Semar's way, are prohibited or may not contain anything that is pornographic, contains elements of racism SARA, public figures memes, or jokes that offend people or groups. Violation of the above and the contents of other posts will be Banned or Blocked permanently.

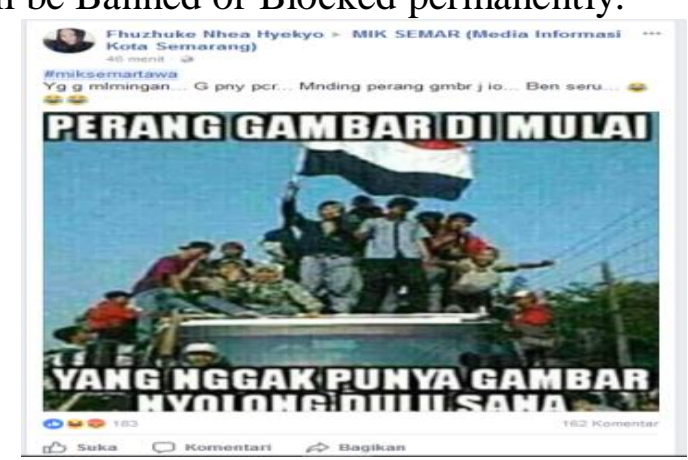

Figure 6. Sample the Use of hashtags \#MIKSEMARTAWA

Those are some types of hashtags (\#) that are often used in the MIK SEMAR Facebook Group, because without the hashtags, uploads will not be able to show up on 
the Groups page. Facebook Group Administartor of MIK SEMAR will not approve every post without using hashtags. Special for uploads with \#MIKSEMARSAPA and \#MIKSEMARSAPA will only be served on Saturdays and Sundays by the manager.

The sign (\#) must be placed before the material or the main information is uploaded. With hashtag in facebook, the text will have a different structure with other text, the text with a hashtag will become thicker or bold. The use of hashtag becomes a distinction between the virtual community of MIK SEMAR facebook group and other virtual communities.

Social media invites anyone to participate by giving feedback openly, commenting, and sharing information in a fast and unlimited time. Social media eliminates restrictions on socializing, such as space and time. Consequently, every individual can communicate whenever and wherever they are (Safko in Hutagalung, 2014: 368).

When the use of hashtags has become a trend, what differentiates regular Internet users and those who belong to a virtual community? in research conducted by TINT (Social Media Aggregator) there are 4 community criteria. First, Self-Identification, members must recognize the limits of membership and they are involved in the internal rules. In MIK Semar is divided into several types of members including the Dalang Utama (Manager), Punggawa (Admin), Provost (Members who are entitled to filter existing information in the Group), and citizens MIK Semar (regular members who can only observe, respond and upload information ).

Second, Influence, members have varying degrees of influence, As explained earlier that each kind of member has a different influence, in MIK Semar a big influence is owned by the Dalang Utama/Manager and Punggawa as administrator.

Third, Shared Emotional Connection. Members feel special because they have joined in the virtual community, so there is a feeling to keep the virtual community running well. To keep MIK Semar group being well organized, the hashtags are used as the identity of messages that all members must be obeyed. Fourth, Fulfillment of needs, one of the underlying people to join a virtual community is to fill the necessity of information and to convey aspirations.

\section{Conclusion}

Based on the analysis from the researcher, Computer Mediated Communication or CMC able to bring the community. Facebook Group MIK Semar is also a part of virtual community where the people surround have the same interest to share information related to events, activities, competitions, entertainment, history, in Semarang city to be published. The use of Hashtags shows topics or themes, and it is an important innovation in social media communication.

The sign (\#) has given a different color in social media, where social media has been equipped with User Generated Content (UGC) which can create citizen involvement in social media. Hashtags has changed how we speak (verbally and nonverbally), hashtags have changed how to sell a product or campaign.

Hashtags has become a media to find the source of content in social media, hashtags has become a new way of doing social movements, it has changed how we build a virtual community As the use of hashtags in the MIC SEMAR Group's Facebook virtual community as a message identity to build better relationships and support communication among its members. 
MIK Semar's Facebook Group, hashtags are no longer used to group or associate similar topics but are used as the message identities of each upload posted to the group, the use of hashtags are required by the group manager to clarify the intent of uploaded messages, such as hashtags \#MIKSEMARTANYA, \#MIKSEMARINFO, \#MIKSEMARPROMOSI, \#MIKSEMARTAWA, \#MIKSEMARSAPA placed at the beginning of the upload. Every member of the community must recognize the limits of membership and they are involved in the rules inside.

\section{Acknowledgement}

The authors would like to thank to all collegues especially teaching staff at Unissula Communication Sciences who have provided suggestions for the development of this research.

\section{References}

APJII. (2016). APJII: Infografis Penetrasi dan Perilaku Pengguna Internet di Indonesia. Retrieved from https://www.apjii.or.id/content/read/39/264/SurveiInternet-APJII-2016.

Bruns, A., Burgess, J.E. (2011). The Use of Twitter Hashtags in the Formation of ad hoc publics. The 6th European Consortium for Political Research General Conference. University of Iceland: Reykjavik.

Dey, I. (1993). Qualitative Data Analysis A User-Friendly Guide For Social Scientists. London and New York: Routledge-Taylor and Francis Group

Facebook. (2017). Peraturan Grup MIK Semar. Retrieved from https://web.facebook.com/groups/MIKSEMAR

Facebook. (2017). Peraturan Memakai Hashtags. Retrieved from https://web.facebook.com/groups/MIKSEMAR/permalink/1571344309649193/

Greenhalgh, T., Taylor, R. (1997). Papers that go Beyond Numbers (Qualitative Research). BMJ: British Medical Journal, 315 (7110), 740.

Hine, C. (2000). Virtual Ethnography. London: Sage.

Huberman, A.M., Miles, M.B. (2009). Qualitative Data Analysis, atau Analisis Data Kualitatif, terjemahan Tjetjep Rohendi. Jakarta: Univ. Indonesia Press.

Hutagalung, I. (2014). 'Etika dan Media Sosial' dalam Masa Depan Komunikasi, Masa Depan Indonesia: Demokrasi Dalam Ruang Virtual. Jakarta: ISKI.

McQuail, D. (2011). Teori Komunikasi Massa McQuail (Edisi 6 Buku 1). Jakarta: Salemba Humanika

Kaplan, A.M., Haenlein, M. (2010). Users of the world, unite! The challenges and opportunities of Social Media. Business Horizons.

Kriyantono, R. (2007). Teknik Praktis Riset Komunikasi. Jakarta: Kencana Prenada Media Group.

Thurlow et al. (2007). Computer Mediated Communication: Social Interaction and the Internet. London: Sage Publication.

Ubayasiri, K. (2006). Internet and the Public Sphere: A Glimpse of YouTube. JOUR., 2. Central Queensland University.

Watie, E.D.S. (2011). Komunikasi dan Media Sosial (Communications and Social Media). Jurnal The Messenger, 3 (2), 69-74.

Watie, E.D.S. (2012). Media Sosial yang Dibenci yang Ditakuti. Jurnal The Messenger, 4 (2), 14-18. 